\title{
Battery fault ends X-ray satellite mission
}

[MUNICH] Astronomers around the world were last week lamenting the likely loss of Abrixas, a small German-built X-ray satellite whose batteries failed two days after a successful Russian launch.

Some were also suggesting that the failure has raised doubts about the apparently high level of risk associated with so-called 'smaller, faster, cheaper' science missions. These are favoured by space agencies in Europe and the United States as a way of introducing more flexibility into their launch schedules (see Nature 389, 899; 1997).

Abrixas was to have carried out the first complete broad-band all-sky survey with imaging telescopes in the medium-energy $\mathrm{X}$-ray range, extending by an order of magnitude the survey performed by its predecessor ROSAT, which was shut down last year.

Abrixas was seen as a pathfinder for future large international X-ray missions, including the European Space Agency's XMM, the US space agency NASA's AXAFrecently renamed the Chandra X-ray Observatory - and Japan's Astro-E.

Scientists on these missions, each scheduled to be launched within the next nine months, had been hoping to study interesting X-ray sources identified by Abrixas.

But ground contact with the satellite was lost two days after its launch. At least one of its eleven battery cells appears to have been burnt out by inappropriate power input from batteries used to support the launch. This means that, although the scientific instruments seem to be working, the information they gather cannot be transmitted to Earth.

Engineers will be able to analyse the full extent of the damage during a six-day period

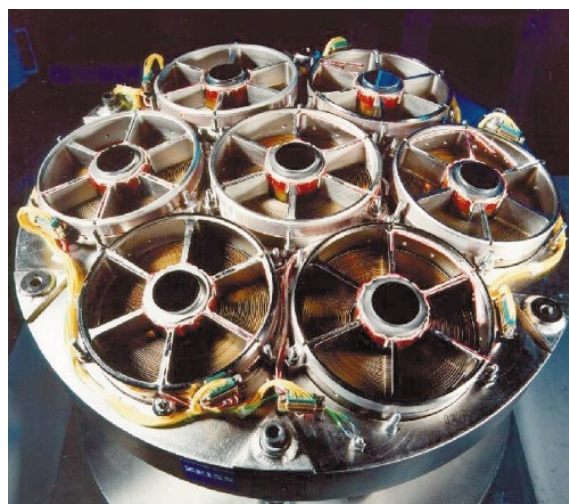

Lost in space: but calibration data from the X-ray telescopes on Abrixas may still be useful.

at the end of next month when Abrixas moves into full sunlight and its solar panels become operational. But it seems unlikely that the battery system can be restored or the satellite's scientific mission fulfilled.

"This is not only a major disappointment to our German colleagues, but also a setback to the international astronomy community," says X-ray astronomer Ken Pounds, professor of space physics at Britain's Leicester University. "We were looking forward to Abrixas pointing the way to the best use of the upcoming international missions."

Claude Canizares, director of the Center for Space Research at the Massachusetts Institute of Technology, and principal investigator of a Chandra instrument, agrees that the situation is "very sad". Not only would Abrixas have helped locate the best targets for Chandra to focus on, he says, but "it is also nice to have relatively low-cost, small, fast and clever missions in one's portfolio".
Canizares says it is disconcerting that "so many small missions seem to be failing". Only a few weeks ago, WIRE, a small NASA satellite that would have surveyed the infrared sky, failed because its protective cover was lost after launch (see Nature 398, $100 ; 1999)$. Solar radiation heated the spacecraft and its store of cryogenic fuel was boiled off within a few days. This ended the mission, as infrared detectors can only function at verylow temperatures in space.

Canizares suggests that the Abrixas failure is likely to fuel debates on how to reconcile speed with quality control.

Martin Turner, professor of astrophysics at Leicester University, and principal investigator on an XMM instrument, echoes the concern about faster, cheaper missions. "The Abrixas people did everything right: they completed to launch within three years, at low cost [DM40 million]," he says. "Yet they were let down by a low-tech item, the batteries."

Abrixas, like most scientific satellites, was not insured. Although the error is believed to be a design fault in the battery system, which was provided by the Bremen-based company $\mathrm{OHB}$, a spokesman for the German space agency DLR, says that, if tests in June prove that the mission is dead, "it is not clear if any form of compensation could be expected".

Joachim Trümper, director of the Max Planck Institute for Extraterrestrial Physics in Garching and head of the Abrixas project, is trying to remain positive. Although Abrixas may never yield scientific data, he says, calibration work on its novel X-ray camera may be done during the satellite's brief sunlight period. The high-tech camera will also fly on XMM.

Alison Abbott

\section{French unions hopeful of delaying reforms until after consultation}

[PARIS] Trade unions representing French scientists were increasingly confident of victory this week in their demand that the government should not undertake any new reforms before the completion of a national consultation on research in July. They appear to have won the support of the prime minister's office.

The unions had called on researchers to support a national day of protest on 11 May to secure this commitment. But on Monday it seemed that the science ministry had bowed to their main demand, postponing an interministerial meeting on research originally scheduled for 18 May.

The unions had argued that the ministry's decision to proceed with the meeting suggested that it would ignore the consultation and push ahead with its own reform plans (see Nature 399, 4; 1999). The ministry countered that the meeting would deal only with strategic research themes and industrial research.

A science ministry spokesperson says the meeting will only be postponed by a matter of days, but Herbert Maisl, science adviser to Lionel Jospin, the prime minister, says it is "cancelled until further notice".

The prime minister's office is now setting the timetable for reform. Jospin himself commissioned the parliamentary mission, following Socialist Party concern that science minister Claude Allègre's attempts to impose reform were opposed by the research and higher education community.

The unions' claims that the science ministry might only pay lip service to the consultation seemed to be strengthened last week by a leaked preparatory document for the meeting. The document, released by the unions on Friday, largely covers the remit of the parliamentary mission, which is led by two Socialist members of the national assembly, Pierre Cohen (Haute-Garonne) and Jean-Yves Le Déaut (Meurthe-etMoselle), a former head of the Parliamentary Office of Scientific and Technological Choices.

Le Déaut plays down the document's significance, arguing that it dates from several months ago. This is confirmed by Jean-Yves Mérindol, vice-chancellor of the University of Strasbourg and chairman of the research committee of the Conference of University Vice-Chancellors.

Le Déaut says Allègre gave him his personal guarantee last week that "no decision would be taken within the remit of our mission until this is completed".

Cohen says any attempt by the interministerial meeting to answer the questions of the mission will not be tolerated. The decision of the prime minister's office suggests that it shares this view. Eric Glover 